\title{
Pedagogical Conditions for Formation of Personal Professional Qualities in Students-Future Math Teachers
}

\author{
Anvar Nuriakhmetovich Khuziakhmetov \\ Rashida Gabdelbakievna Gabdrakhmanova
}

Kazan (Volga Region) Federal University, 420008, Kazan, Russia

\section{Doi:10.5901/mjss.2015.v6n4s1p219}

\begin{abstract}
A modern school needs a teacher, who is able to cooperate, with high level of mobility, dynamism, creative talent, with deep professional knowledge, competencies. High level of requirements in professional training of future specialists conditions a large volume of theoretical knowledge, practical knowledge and skills, competencies, which the student shall acquire during his studying in the university. At that, high competitiveness at labor market requires constant professional self-improvement and personal growth. The purpose of investigation is to determine the pedagogical conditions, promoting the successful formation of professionally significant personal qualities in students-future teachers of mathematics. The structure of personal professional qualities of the students presents a complex formation, consisting of three interconnected components: creative; cognitive and emotional-volitional. A system work was carried out on each structural component. The implementation of complex of pedagogical conditions for formation of personal professionally significant qualities in students-future math teachers was executed due to organization of pedagogical work in the universities in different forms: extracurricular activity, specially organized for development of creative projects, the educational process itself. The indicators of the results of executed pedagogical experiment prove, that the specified pedagogical conditions provide the effective formation of personal professionally significant qualities in students-future math teachers. The indicators of formedness of structural components of personal professionally significant qualities (cognitive, creative, emotional-volitional) were higher in experimental group. Positive dynamics in formation of personal professionally significant qualities per each of three components is definitely expressed in experimental group; the degree of reliance is lower in the control group. The results of experiments show, that the pedagogical conditions, which we distinguished in the course of experiment, promote the formation of personal professionally significant qualities in students-future math teachers, and also increase the effectiveness of professional development.
\end{abstract}

Keywords. Teacher, professional qualities, creativity, level of professionalism, socialization, pedagogical conditions.

\section{Introduction}

In Russia, against the background of world economic crisis, the sociocultural and economic situation is being changed torrentially. We observe the labor market competition that is why the employers increase the requirements to professional and personal qualities. In this connection, the specific peculiarities of higher pedagogical education are revealed (Novikov, A.N., 2013), (Gorbunov, A.P., 2013). Today, the educated people, able to make responsible decisions by themselves, collaborative, with high level of mobility and dynamism, are required. The specialist's state of being relevant in labor market mainly depends on his successful socialization, professional adaptation. Socialization is a process and result of social development of the person, the interaction process with social environment, in the course of which he acquires social roles, norms, rules and standards of behavior (Gabdrakhmanova, R.G., 2012), (Khuziakhmetov, A.N., 2006). The dynamics of socialization of the future teacher in the process of professional training is also noted (Chernova, O.V., 2000). In order to achieve a high level of professionalism in any sphere of activity, a person needs to possess a definite volume of professional knowledge and skills, specific competencies, and also a complex of personal qualities, which will promote the successful implementation of professional activity by the person (O'Sulliven M., 1975), (Light, G., 2001), (Jerissa de Bilde, 2011). High competitiveness of profession requires constant professional self-improvement and personal growth (Abramova, G.S., 2000), (Abulkhanova, K.A., 1999). The analysis of existing investigations and practical experience allowed us defining the following contradictions between: modern requirements to organization of education/up-bringing process in the universities and insufficient theoretical development of creation of pedagogical conditions, promoting the formation of personal professional qualities of future math teachers; between the modern requirements to the level of training of future math teachers in constantly varying socium and the existing forms, methods and content in organization of pedagogical work in the university. These circumstances promoted the selection of topic for 
investigation, the problem of which is formulated in the following way: pedagogical conditions for formation of personal professional qualities in students-future math teachers.

\section{Procedure}

To solve the task, we used general scientific methods of theoretical research: the analysis of psychological-pedagogical scientific literature, methodical literature; methods of experimental investigation. The structure of personal professional qualities of students-future math teachers - presents a complex formation, consisting of three interconnected components: a) creative (creative attitude towards the profession, qualities of creative personality, creative components of cognitive activity, research activity); b) cognitive (structural components of cognitive activity, realization of value of pedagogical profession, open-mindedness, information competence, communicative skills); c) emotional-volitional (psychic states, peculiarities of motivational-consumption sphere of the personality, capacity for self-regulation and reflection). The implementation of complex of pedagogical conditions, which would provide the formation of personal professionally significant qualities in students-future math teachers, was executed due to organization of pedagogical work in the universities in different forms: extracurricular activity, specially organized for development of creative projects, the educational process itself. A system of pedagogical conditions for formation of personal professionally significant qualities of students-future math teachers shall include the following components: forms of pedagogical work organization, the content of personal-developing pedagogical activity (creative project development), methods and means of pedagogical provision, ways of organization of students' activity, psychological-pedagogical support of individualpersonal development of students. Purposeful formation of some professionally significant qualities will provide the progressive development of the other qualities. The teenage is a period of ontogenesis, sensitive for creative development of personality and formation of professionally significant qualities (Abulkhanova, K.A., 1999). In teenage period, there is observed the development of individual logical thinking, conception memory, individual style of mental activity, interest to scientific search, easiness of generation of ideas etc; there are created the most favorable conditions for formation of self-consciousness in the unity of three structural components - cognitive, emotional-value-conscious, regulative (Kon, I.S., 1989). The analysis and generalization of results of numerous scientific investigations provides an opportunity to specify the pedagogical conditions for formation of personal professionally significant qualities in studentsfuture math teachers. 1. Creative component. There are distinguished the external conditions of development of personal creative potential and the internal conditions, which are directly connected with personal characteristics of subjects of educational process. The main condition to develop the creative potential is the specially organized creative activity. 2 . Cognitive component. Specifying the pedagogical conditions for developing of personal creative potential, as applied to the profession of math teacher, it is important to mention the necessity to carry out the purposeful pedagogical work in the university, providing the development in students of such constituents of cognitive activity, as creative imagination, divergent (creative) thinking, cognitive activity (Konova, E., 2010). 3. Emotional-volitional component. The success in professional activity depends not only and not so much on the developed professional skills, but on the development of general psychological culture of future math teacher. Thus, the maturity of emotional-personal sphere of the student becomes one of the main factors for training of future specialist and his life quality. The development of "emotional intelligence" implies constant identification by the person of both his own emotions, and the emotions of other people. A significant role in the course of identification of emotions by the person is played by the reflexive processes.

\section{The Results of the Experiment}

The investigation was carried out based on the Kazan (Privolzhsky) Federal University and involved three stages. During the first stage, the scientific-methodical literature was analyzed for the problem of investigation; there were determined the main approaches to development of system of pedagogical conditions for successful formation of professionally significant qualities in students-future math teachers. Relevant character of investigation was explained; the working hypothesis was formulated. During the second stage, the conceptual points of personal professional formation was understood; in order to check the hypothesis, there were determined the pedagogical conditions, required to provide the effectiveness of formation process of professionally significant qualities in students-future math teachers. The experimental part of investigation was carried out. During the third stage, the statistical processing of the results of testing-experimental work was executed; the theoretical conclusions were specified; the materials of testing-experimental work were recorded. The experimental group (EG) and control group (CG) involved the students of 1st and 2nd courses of the Mechanics and Mathematics Institute of the Kazan (Privolzhsky) Federal University, course of training is 050100.62 Pedagogical Education. The experimental group (EG) involved 36 students (2 academic groups), the control group (CG) 
involved 38 students. The members of the academic teaching staff of the Department of Training and Education of the Psychology and Education Institute also took part in the testing-experimental work. At the forming stage of the experiment, a system of pedagogical conditions for formation of personal professionally significant qualities in studentsfuture math teachers was developed and tested. Two main forms of organization of pedagogical work in the university were involved. 1. Extracurricular activity: a) professional-creative education (visit to the exhibitions, museums, theatres, master-classes; meet-the-artist events with the representatives of future professions; research activity of students; participation in exhibitions of students works); b) cultural-leisure activity (rag days, participation in preparation to nationwide holidays, creative contests, clubs etc.) 2. Specially organized pedagogical work with students-future mathematics teachers for formation of their complex of personal professionally significant qualities, based on execution of creative works. (Priority provision of formation of emotional-volitional component). Besides, the content of educational process in experimental academic subgroups was enriched with active training methods and devices to stimulate cognitive activity, methods and devices to develop the divergent thinking and creative imagination, and the organization of students' research activity. Methods and devices of pedagogical provision of formation of personal professionally significant qualities in students-future math teachers. 1. Cognitive component. Methods and devices to enrich the sphere of images: preparation of thematic messages, reports, reviews; preparation of thematic presentations; method of excursions; method of personal example (meet-the-artist events with the representatives of future profession) etc. Methods and devices to develop the cognitive activity: discussion of problematic situations; searching the answers to the questions (partially-searching, searching, problematic, specifying, generalizing); the use of educational resources of different type (printed, Internet, video, etc.) as a means of intellectual-cognitive activity; participation in research projects; debates; reader's conferences; round table. 2. Creative component. Methods and devices to develop the creative imagination: "Vice versa" (the search for alternative way to solve the problem), "Good - bad" (the analysis of advantages and disadvantages of any phenomenon, solution, way to overcome difficulties), method of "role reverse" (the discussion of the situation, search for possible ways to solve the problem from a perspective of different people); etc. Methods and devices to improve the skills of creative activity: creative tasks, creative projects, participation in exhibitions, contests, festivals, creation of "situation of success", encouragement, help, approval etc. 3. Emotional-volitional component. Methods and devices to develop the emotional-affective sphere: verbalization of emotions, self-analysis - selfpresentation (self-actualization of "I" image), the work in circle (discussion of problem; exchange of opinions, impressions), "travel to picture" etc. Methods and devices to correct the emotional states and development of voluntary regulation: psychological structuring, positive adjustment, the use of devices of wishful thinking, rationalization, relaxation to music, rational organization of activity (problem setting, task definition, activity planning, determination of ways to achieve the target goal and tasks, distribution of duties between participants), self- and mutual control over the execution of activity, timely correction of emerging problems etc. The ways to organize the students' activity: 1) collective activity (work in circle on private problems discussion, preparation to cultural-leisure events, participation in exhibitions of creative works, attendance of master-classes etc); 2) work in micro-groups of 2-4 people (execution of creative projects etc.); 3) individual activity (writing of essay, preparation of messages, execution of investigation etc.).

\section{Discussion}

The structure of professional training is considered as a unity and interconnection of substations, psychological and private aspects, which are implemented in the process of this training (Martinet, M.A., 2001), (Richards J.C., 2005). The provision of development of creative imagination of students-future mathematics teachers is achieved due to the use of special exercises and creative tasks (creative projects) in educational process (Hutchinson, T ., 1999). In the educational process, it is necessary to overcome factors in time, which prevent the students from activation their creative imagination: a need for achievement, by any means; a fear of risk on the part of the student and non-admission of risk on the part of the teacher; conformity, inability to confront the pressure of others; regulation of behavior; disapproval of students' doubts, personal opinions and thoughts by the teacher; readiness to change personal opinion under the influence of coevals or elders; idealization of authorities (Campbell, C., 2007), (Alexander, R.J., 2008). As the intellectual and personal components are closely connected in the development of cognitive activity, the great interest presents the methodology of new conceptual treatment of research cognitive activity, as the activity of productive, creative type, developing and implementing in the form of internal (in the reflexive self-consciousness of the person) dialogue or external dialogue (in interpersonal communication of partners in cooperative or joint work). The scientists were always interested in the problem of competence and quality in the system of higher education (Bowden, J., 1998). Western scientists define the professional competence as "profound knowledge", "the state of adequate executions of tasks", "capacity for relevant execution of activity" (G.K.Britell, R.M.Jueger, W.E.Blank). 


\section{Conclusion}

The results of the experiment are the following: 1. According to the indicator of formedness of all structural components of personal professionally significant qualities in students-future math teachers (cognitive, creative, emotional-volitional) of the EG and CG, it is higher in EG per each of three components. 2. Positive dynamics of formation of personal professionally significant qualities in students-future math teachers per each of three components is definitely shown in EG; the degree of reliance is lower in CG. 2. Thus, the results of pedagogical experiment, in whole, showed the effectiveness of implementation of the pedagogical conditions system at the forming stage of experiment; they provide the formation of personal professionally significant qualities of students-future math teachers, if the pedagogical work is organized in the university.

\section{Summary}

We revealed and experimentally checked the pedagogical conditions, providing the formation of personal professionally significant qualities in students. In future, it is possible to continue the study and to extend the system of pedagogical conditions, distinguished in our investigation.

\section{References}

Abramova, G.S., 2000. Practical Psychology. M.: Academy, pp: 228.

Abulkhanova, K.A., 1999. Psychology and Consciousness: Selected Psychological Works. M., Voronezh: MODECK Publisher, pp: 224.

Gabdrakhmanova, R.G. and S.F. Egereva, 2012. Poly-Professional Approach to Counter-Drugs Upbringing of Young People, as a Factor of Personal Self-Development. Education and Self-Development, 4: 126-131.

Gorbunov, A.P., 2013. Transforming (Creative-Innovative) University as an Answer to Challenges of New Epoch. Higher Education in Russia, 8/9: 42-59.

Elantseva, S.A., 2013. Psychological Aspects of Professional Training of Future Teacher in the University. Higher Education in Russia, 11: $125-130$.

Kon, I.S., 1989. The Psychology of Early Youth. M.: Prosveshenie, pp: 252.

Konova, E.V., 2012. The development of social creativity of future youth specialists in educational environment of the university. PhD thesis, Tula State Pedagogical University named after L.N. Tolstoy, Tula.

Novikov, A.N., 2013. Higher Pedagogical Education in Conditions of Reorganization of Pedagogical Institutes. Higher Education in Russia, 10: 34-38.

Khuziakhmetov, A.N., 2006. Formation of the Pupil's Personality: Problem of Socialization and Individualization. Kazan: Delo, pp: 225.

Chernova, O.V., 2000. The dynamics of socialization of the future teacher in the process of professional training (at the example of pedagogical institute). PhD thesis, Kazan.

Alexander, R.J., 2008. Towards Dialogic Teaching: Rethinking Classroom Talk (4th edition), Dialogos, UK.

Campbell, C., 2007. Learning-Based Teaching. Oxford University Press, pp: 126.

Collins, R., 2004. Interaction Ritual Chains. Princeton University Press.

Hutchinson, T., 1999. Introduction to Project Work. Oxford: Oxford University Press.

Isaacs, W., 1996. The Process and Potential of Dialogue in Social Change. Educational Technology, pp: 20-30.

de Bilde J., 2011. Understanding the Association between Future Time Perspective and Self-Regulated Learning through the Lens of Self-Determination Theory. Learning and Instruction, 21 (3): 332-344.

Light, G., 2001. Learning and Teaching in Higher Education: The Reflective Professional. Routledge Falmer, pp: 288.

O'Sulliven, M. and J.P. Gilford, 1975. Six Factors of Behavioral Cognition: Understanding Other People. Journal of Educational Mea Sûrement, 12: 255-271.

Bowden, J., 1998. The University of Learning: beyond Quality and Competence in Higher Education. London: ICogan Page.

Martinet, M.A., 2001. Teacher Training: Orientations, Professional Competencies. Government of Quebec Ministry of Education.

Richards, J.C., 2005. Professional Development for Language Teachers. Cambridge: CambridgeUniversity Press. 